\title{
The Theoretical Embedding Of Born Globals: Challenging Existing Internationalization Theories
}

Ricarda B. Bouncken, University of Bayreuth, Germany

Felix Schuessler, University of Liechtenstein, Germany

Sascha Kraus, University of Liechtenstein, Germany

\begin{abstract}
This article examines the embedding of the phenomenon of Born Globals into three existing theories of the firm. The model of Born Globals deals with young companies that begin shortly after their foundation to internationalize. The Uppsala Internationalization Model helps to delimit the concept of Born Globals from existing internationalization models and to highlight their special features. The resource-based view takes up the integration of knowledge as the key resource of Born Globals and explains the underlying mechanism with which a company achieves a sustainable competitive advantage from a bundle of resources. The knowledge-based view is concerned with the generation of knowledge and explains the learning processes that are performed by the entrepreneur. A recurring theme could be identified and contains the following elements which interconnect the three theories of the firm with the concept of Born Globals knowledge as a key resource, learning, and integration of knowledge into organizations.
\end{abstract}

Keywords: Born Globals; Uppsala Internationalization Model; Resource-Based View; Knowledge-Based View

\section{INTRODUCTION}

ince the scientific community debates about business enterprises, theories and models are developed to explain their reason for existence and to understand their structures and behaviors. Thereby, each theory represents a blueprint of the real world but is designed to address only a particular set of its characteristics (Machlup, 1967). "As a result, there are many theories of the firm which both compete in offering rival explanations of the same phenomena and complement one another in explaining different phenomena." (Grant, 1996, p. 109)

With changing environmental conditions in the real world, the need arises to question old theories (and to discard them sometimes), to develop them further, or to build a new concept. Globalization is such a far-reaching change that faces especially companies with entirely new challenges and destroys some old concepts (Root, 1994). As "[...], a development where the boundaries between the different countries in the world are increasingly blurred [...]" (Solberg, 1997, p. 27), globalization also spawned new phenomena, such as the Born Globals (BGs); i.e., firms that are active on more than just their home market quasi from birth on, and led to new discussions in the context of the internationalization process of firms (Oviatt \& McDougall, 1997).

Whenever new subjects and theoretical concepts are proposed, one should ask, "what is different from what we already know?" This paper picks up three existing theories of the firm and links them with the phenomenon of BGs. The aim of this article is to identify elements in the theories that help to explain and to gain a better understanding of this new concept. Moreover, it should be examined to what extent the concept of BGs is suited to rethink old paradigms or to develop existing theories further. 
In times of ubiquitous globalization in areas like politics, economy or technology, more and more small entrepreneurial companies start their international activities very soon after their establishment (Oviatt \& McDougall, 1994; Rialp, Rialp, \& Knight, 2005). The main reasons for this development are trends like the increasing importance of niche markets, which forces small firms into small niches in several countries in order to be competitive, or the rapid development of advanced communication technology, which accelerates the transfer of information around the globe and facilitates to expand global networks and alliances (Moen, 2002).

BG has evolved as the most common term used to describe this phenomenon, which has caused the rapid growth of international entrepreneurship as a research field in the last decade (Andersson, 2011; Moen, Sørheim, \& Erikson, 2008). Because of the various contexts, and thus different conditions for internationalization, in which the phenomenon occurs, a singular definition seems to be inappropriate and always has to be adapted to the specific context, respectively; it has to be positioned in a definitional corridor (Cesinger, Fink, Madsen, \& Kraus, 2012). Knight \& Cavusgil (2004) explored the phenomenon for the first time in conjunction with the role of innovative culture, knowledge and capabilities and define BGs " $[\ldots]$ as business organizations that, from or near their founding, seek superior international business performance from the application of knowledge-based resources to the sale of outputs in multiple countries." (p. 124) Unlike more traditional internationalization models in which firms operate in their domestic markets for many years and then start to expand the international business step by step, BGs have a global view of their markets from the beginning and develop the capabilities needed to achieve their international goals on the job (Knight \& Cavusgil, 2004).

Bingham and Davis (2012) mentioned that gaining more organizational capabilities is closely related to the way of learning. Because of the need to educate themselves quickly about a foreign market, companies have developed a variety of approaches - direct approaches to learning, like trial and error, experimentation, improvisation, or deviance error, and indirect approaches to learning, like vicarious or advice. The most successful approaches were combinations made from direct and indirect learning (Bingham \& Davis, 2012).

The acting individual; i.e., the manager or entrepreneur, seems to be the key element for a rapid and successful internationalization of BGs; it brings together both the international business experience and the international network of individuals and firms (Park \& Rhee, 2012). Their international business experience provides access to profitable business opportunities in foreign markets (Bloodgood et al., 1996). Frequent network activities can help to acquire resources and knowledge, thus accelerate the entrance in foreign markets, and can be the decisive advantage over the competitors (Acedo \& Jones, 2007; Oviatt \& McDougall, 1994). Especially against the background of limited own resources, the ability of BGs to take possession of external resources and knowledge becomes an important factor and absorptive capacity becomes the key competence (Cohen \& Levinthal, 1990).

\section{THEORETICAL FOUNDATION OF THE THEORIES OF THE FIRM}

\subsection{Uppsala Internationalization Model}

The Uppsala Internationalization Model is based on the learning theory (Johanson \& Vahlne, 1977) and goes back to theories of behavior of companies (such as described in the work of Aharoni, 1966, and Penrose, 1959). The model describes internationalization as a dynamic and evolutionary process in which the company enhances its international activities gradually (Johanson \& Vahlne, 1977; 1990; Petersen \& Pedersen, 1997). The internationalization process is described in single phases in which the state of the status quo alternates cyclically with a state of change - before a change is initiated, first market commitment and market knowledge must be generated in a company. If these basic requirements are met, a period of change begins in which new decisions (based on the gained experience) in terms of the internationalization can be made (Forsgren, 2002; Steen \& Liesch, 2007).

The basic assumption of the theory is that companies have no or very limited knowledge of international markets at the beginning of the internationalization process and they therefore venture initially only small steps in this new area. Hence, the concept of psychic distance (which describes e.g. differences and similarities in culture, 
language, political system and level of education between countries) plays an important role in terms of the order in which the foreign markets are entered. During the internationalization process, however, new knowledge is generated and more and more resources of the company are gained by increasing engagement in international business (Johanson \& Vahlne, 1977). Thus, learning is a central point in the Uppsala model; companies must first pass a learning curve before they are able to start new internationalization activities (Johanson \& Vahlne, 1977). Knowledge (and, in particular, tacit knowledge) is taking the performance-critical role in the internationalization process (Johnson, 1988; Lindblom, 1959).

\subsection{Resource-Based View}

The resource-based view rests on the theory that firms, due to their inherent resources and capabilities, have different strengths. These resources must be valuable, rare, difficult or impossible to imitate and should not be replaceable by substitutes. Only then a sustainable competitive advantage can be approached and the company is able to reach its goals and work more efficiently (Barney, 1991). Barney (1991) describes the resources of companies as "[...] all assets, capabilities, organizational processes, firm attributes, information, knowledge, etc. controlled by a firm that enables the firm to conceive of and implement strategies that improve its efficiency and effectiveness." (p. 101) Some examples of resources are brand names, in-house knowledge of technology, employment of skilled personnel, trade contacts, machinery, efficient procedures, or capital (Wernerfelt, 1984, p. 172). Several authors have shown, in their studies, the link between unique resources of a company and the scope and progress of internationalization (Dhanaraj \& Beamish, 2003; Westhead, Wright, \& Ucbasaran, 2001). In the resource-based view, the resources and products of a company are the two sides of a coin - "Most products require the services of several resources and most resources can be used in several products." (Wernerfelt, 1984, p. 171) The existing resources within a company (and the ability to use them effectively) determine the degree of flexibility which can be used to operate in an uncertain environment. A company provides the structures, makes strategic decisions and coordinates intra- and inter-firm resources to encounter this uncertainty (Fredericks, 2005).

Besides the ability to combine resources effectively, the characteristics of a company to establish partnerships gain more and more importance. Massukado-Nakatani and Teixeira (2009) describe the organizational architecture of a company (as one of four skills) as "[...] a contract where it can establish relationships with or between its employees - internal architecture -, with its suppliers and customers - external architecture - or, enters a group of companies engaged in correlated activities." (p. 66) This organizational architecture, which is complimentary to Barney's (1991) organizational resources, emphasizes the importance of partnerships and constitutes the concept of resource network.

\subsection{Knowledge-Based View}

Building on the resource-based view (in which knowledge is seen as a key resource), an independent theory model was developed - the knowledge-based view is linked to the generation of knowledge within organizations. Various authors see knowledge, even as the primary resource that creates new value, heterogeneity and competitive advantages (Barney, 1991; Grant, 1996; Kogut \& Zander, 1992). The model lays the focus on the interaction of individuals who supplement their individual knowledge through cooperation with partners abroad and, as a result, the whole resource of the company increases (Conner \& Prahalad, 1996).

The knowledge-based view argues that the existing knowledge of an individual depends on his or her particular experiences, insights or skills that differ from each other. Tacit knowledge, for example, can only be learned individually and is very difficult to transfer (Nelson \& Winter, 1982; Nonaka, 1994; Polanyi, 1962). Liebeskind (1996) defines knowledge as "[...] information whose validity has been established through tests of proof." (p. 94) and borders it from other forms of "unproven" information, e.g. opinion, speculation or beliefs. Thus, the definition approach is very broad and includes both codified knowledge products (e.g. documents), as well as uncodified routines (tacit knowledge). In the knowledge-based view, new knowledge can emerge through investing in innovation and test of proof. Because this investment is related to high costs and the process is full of uncertainty, valuable knowledge is hard to transfer and therefore becomes a competitive advantage for a company (Winter, 1987). The model requires that knowledge can be protected by an enterprise as an asset against theft and imitation and that others may be deterred from its use. Although a physical product, for example, can be disassembled and can 
be relatively easily assessed, the manufacturing process, however, is much more difficult to imitate (Liebeskind, 1996).

\section{THEORETICAL INTEGRATION OF BORN GLOBALS}

\subsection{Challenging The Uppsala Internationalization Model}

In order to describe the differences and similarities between the concept of BGs and the Uppsala model, it is important to investigate how both schools view key parameters. In the traditional Uppsala approach, companies first develop the domestic market in which they were established, start their foreign operations from culturally and geographically close countries, and move gradually to more distant markets. The first foreign sales begin with occasional export orders (Johanson \& Vahlne, 1977; Johanson \& Wiedersheim-Paul, 1975). The theoretical perspective describes internationalization as a consequence of a series of incremental decisions, preceded by a learning process. The conquest of foreign markets is essentially limited by the existing knowledge and other resources. The internationalization process runs through a domestic phase, an international phase and ends in the global phase (Johanson \& Vahlne, 1977).

In contrast to the old theoretical internationalization approach with its typical phases, BGs jump straight from the domestic to the global phase - a phenomenon also known as leap frogging (Fink, Harms, \& Kraus, 2008; Gabrielsson, Gabrielsson, \& Seppälä, 2012). Seven reasons can be found which support the rapid internationalization of BGs (Freeman, Edwards, \& Schroder, 2006): (1) domestic market that is perceived as too small to achieve financial viability, (2) strong commitment by senior management to the idea of internationalization, (3) personal networks that provide the basis for establishing partnerships and alliances, (4) unique technology that provides a source of competitive advantage, (5) commitment to growth through partnerships and alliances with both suppliers and distribution partners, (6) adaptation of relationships over time so that they are sustained and meet the changing needs of partners, and development of new relationships to enter new product markets, and (7) the use of multiple entry modes in different combinations for different markets.

\subsection{Meeting The Resource-Based View}

The resources-based view provides the superior (international) performance as a result of a bundle of resources and capabilities that exist in a company. The main purpose of a company is to coordinate these resources, to combine them in new way and to generate a new value. Thus, the existing resources and their quality represent the limitation factor in achieving long-term success in the market. According to the theory model, the resources need to have the following properties: (1) valuable, (2) rare, (3) imperfectly imitable, and (4) non-substitutable (Barney, 1991; Peteraf, 1993; Wernerfelt, 1984). In practical terms, however, it is not that easy to find physical (tangible) resources which satisfy simultaneously all of these properties. Intangible goods (to which knowledge belongs) may meet the requirements more likely.

This results in a tie point for the BG theory - in this type of firm, it is mainly the humane resource, and thus tacit knowledge, which substantially contributes to competitive advantage. This leads to another very important parallel between the two models - BGs develop the capabilities needed to achieve their international goals on the job (Knight \& Cavusgil, 2004). These capabilities are dynamic, include the ability to constantly renew the firm's competence and help to adapt to the changing environment (Teece, Pisano, \& Shuen, 1997). Studies have shown, that the strongly innovative nature of BGs is the main factor driving the development of organizational capabilities, thereby supporting the early internationalization and superior performance in foreign markets (Knight \& Cavusgil, 2004).

\subsection{Parallels To The Knowledge-Based View}

The theory model of the knowledge-based view focuses on knowledge as a resource and puts the acting individual in the center point. Also in the BG theory, the acting individual (the manager or the entrepreneur) seems to be the key element for a rapid and successful internationalization of BGs; it brings together both the international business experience and the international network of individuals and firms (Park \& Rhee, 2012). Their international business experience provides access to profitable business opportunities in foreign markets (Bloodgood et al., 1996). 
Frequent network activities can help to acquire resources and knowledge, thus accelerate the entrance in foreign markets, and can be the decisive advantage over the competitors (Acedo \& Jones, 2007; Oviatt \& McDougall, 1994).

\section{DISCUSSION AND REFLECTION}

The embedding of the phenomenon of BGs in the three theory models has shown some parallels, but also represented attachment points that differ from the existing models. The Uppsala model seems to be no longer sufficient to explain the phenomenon of BGs, because they are particularly defined by differing from the traditional approach and not following a regular path of internationalization. The main differences between the two models can be explained in the following points:

1. Speed: The reason for BGs' fast internationalization is gaining a competitive advantage of being a first mover of a new product, whereas the strategic drive of the Uppsala model is to first build up enough resources to take advantage of economies of scale it can use against competitors in international markets (Gabrielsson \& Kirpalani, 2004).

2. Scale: BGs include already-at-market-entry the entire globe as a potential marketplace and do not remain in the domestic market (Knight \& Cavusgil, 2004; Madsen \& Servais, 1997; Oviatt \& McDougall, 1994; Rennie, 1993).

3. Scope: The traditional internationalization pathway follows the establishment chain, whereas BGs consider the risk associated with the internationalization to be not as high and make their decisions in terms of internalizing or externalizing activities to enhance the effectiveness of the firm (Andersson \& Wictor, 2003; Oviatt \& McDougall, 1994).

The resource-based view focuses not only on the specific resources of a company but also on the needed capabilities to combine these resources effectively (Helfat \& Peteraf, 2003). These capabilities play an important role in terms of acting in dynamic markets with rapid and unpredictable changes (Eisenhardt \& Martin, 2000; Teece, 2007), because they are prerequisite to "[...] integrate, build, and reconfigure internal and external competencies to address rapidly changing environments." (Teece et al., 1997, p. 516) BGs are confronted immediately as soon as they are founded with a very volatile environment and a high uncertainty due to the simultaneous development of several markets. Like the most start-up companies, BGs usually have only limited resources and need to provide a high level of coordination over national borders. To understand why BGs are superior in handling these constraints, one has to dip deeper into the mechanism of dynamic capabilities; on the organizational level, these capabilities are described as learned and stable patterns of collective activity through which firms generate and modify their operating routines to enhance their effectiveness (Zollo \& Winter, 2002). However, the resource-based view is mainly limited to the processes that occur within an organization; but in terms of the pathway of knowledge, the model should be expanded and also include the external sources of knowledge. Lichtenthaler and Lichtenthaler (2010) brought a new concept into the discussion, called desorptive capacity, as a complement to the concept of absorptive capacity: "While absorptive capacity refers to a firm's ability to recognize, assimilate, and apply external knowledge, desorptive capacity describes a firm's ability to transfer its own knowledge to external partners." (p. 166) In conclusion, this means that the ability to transfer market knowledge (as the key resource of BGs) depends not only on the dynamic capabilities of the organization to integrate external knowledge, but it although depends on the capabilities of the foreign partners to transfer their knowledge (Lichtenthaler \& Lichtenthaler, 2010).

The knowledge-based view focuses on knowledge as the most important resource and argues that firms exist "[...] because they can create conditions under which multiple individuals can integrate their specialist knowledge." (Grant, 1996, p. 112) The theory is concerned primarily with the generation of knowledge and puts the individual in the center of the learning process. "All learning takes place inside individual human heads; an organization learns in only two ways: 1) by the learning of its members or 2) by ingesting new members who have knowledge the organization didn't previously have." (Simon, 1991, p. 125) Managers in BGs have developed specific learning strategies which help them to acquire new knowledge very fast (Bingham \& Davis, 2012). BGs benefit from the knowledge of foreign markets, not only through an improved decision-making basis (for example, for choosing the right market entry strategy), but reduce at once the perceived uncertainty and the fear associated with it (Spender, 1996). 


\section{CONCLUSION}

In the embedding of the phenomenon of BGs in the three theories of the firm, one central theme was revealed - the Uppsala Internationalization Model has highlighted a number of points in which BGs differ from traditional companies and their internationalization process. Because the definition approaches of BGs are partly based on these differences, a demarcation to the Uppsala model is possible and the "raison d'etre" of the new concept BGs is given. The resource-based view helps to understand the mechanisms by which companies generate value from a bundle of resources and thus achieve sustained competitive advantage. Concepts, such as desorptive capacity, can supplement the model reasonable and include also the networks and partners, which are an important source of resources for BGs. In a highly globalized world, in which information flows can be exchanged more quickly by modern technologies, knowledge has become a key resource for which BGs have developed perfect skills to make use of them. The knowledge-based view is mainly concerned with the individual and helps to understand the learning process.

As different as the three presented theories of the firm are, they all contain elements that connect them with each other and play an important role for BGs; already the Uppsala model describes incremental learning in the internationalization process of firms, which generates as a result new knowledge as a resource. Both the resource knowledge and the learning processes of individuals are taken up by the resource-based view and are developed further. The knowledge-based perspective contributes to a better understanding of the mechanism of absorptive capacity and dynamic capabilities that deal with the integration of knowledge in an organization.

\section{FUNDING}

This publication was funded by the German Research Foundation (DFG) and the University of Bayreuth in the funding programme Open Access Publishing.

\section{AUTHOR INFORMATION}

Ricarda Bouncken is Chair Professor of Strategy and Organization at the University of Bayreuth, Germany. Her research centers on diversity, innovation, and collaboration. E-Mail: bouncken@uni-bayreuth.de. (Corresponding author)

Felix Schuessler is a doctoral student at the Institute of Entrepreneurship at the University of Liechtenstein. Prior to this, he completed his MSc in Entrepreneurship at the University of Liechtenstein and his BA in Banking and Finance at the Baden-Wuerttemberg Cooperative State University (DHBW). E-mail: felix.schuessler@uni.li.

Sascha Kraus is a Professor for Entrepreneurship at the University of Liechtenstein and a Visiting Professor at the University of St. Gallen, Switzerland, and Utrecht University, The Netherlands. He is also an Adjunct Professor at Lappeenranta University of Technology, Finland. E-mail: sascha.kraus@unisg.ch.

\section{REFERENCES}

1. Acedo, F. J., \& Jones, M. V. (2007). Speed of internationalization and entrepreneurial cognition: Insights and a comparison between international new ventures, exporters and domestic firms. Journal of World Business, 42(3), 236-252.

2. Aharoni, Y. (1966). The foreign investment decision process. In P. J. Buckley \& P. N. Ghauri (Eds.), The Internationalization of the Firm (pp. 1-13). London: International Thomson Business.

3. Andersson, S. (2011). International entrepreneurship, born globals and the theory of effectuation. Journal of Small Business and Enterprise Development, 18(3), 627-643.

4. Andersson, S., \& Wictor, I. (2003). Innovative internationalisation in new firms: born globals - the Swedish case. Journal of International Entrepreneurship, 1(3), 249-275.

5. Barney, J. (1991). Firm Resources and Sustained Competitive Advantage. Journal of Management, 17(1), 99-120.

6. Bingham, C. B., \& Davis, J. P. (2012). Learning Sequences: Their Existence, Effect, and Evolution. 
Academy of Management Journal, 55(3), 611-641.

7. Bloodgood, J., Sapienza, H., \& Almeida, J. (1996). The internationalization of new high-potential US ventures: antecedent and outcomes. Entrepreneurship Theory and Practice, 20(4), 61-76.

8. Cesinger, B., Fink, M., Madsen, T. K., \& Kraus, S. (2012). Rapidly internationalizing ventures: how definitions can bridge the gap across contexts. Management Decision, 50(10), 1816-1842.

9. Cohen, W. M., \& Levinthal, D. A. (1990). Absorptive Capacity: A New Perspective on Learning and Innovation. Administrative Science Quarterly, 35(1), 128-152.

10. Conner, K. R., \& Prahalad, C. K. (1996). A Resource-Based Theory of the Firm: Knowledge Versus Opportunism. Organization Science, 7(5), 477-501.

11. Dhanaraj, C., \& Beamish, P. W. (2003). A Resource-Based Approach to the Study of Export Performance. Journal of Small Business Management, 41(3), 242-261.

12. Eisenhardt, K. M., \& Martin, J. A. (2000). Dynamic capabilities: what are they?. Strategic Management Journal, 21(10), 1105-1121.

13. Fink, M., Harms, R., \& Kraus, S. (2008). Cooperative internationalization of SMEs: Self-commitment as a success factor for International Entrepreneurship. European Management Journal, 26(6), 429-440.

14. Forsgren, M. (2002). The concept of learning in the Uppsala Internationalization Process Model: a critical review. International Business Review, 11(3), 257-277.

15. Fredericks, S. (2005). Cognitive Reflection and Decision Making. Journal of Economic Perspectives, 19(4), 25-42.

16. Freeman, S., Edwards, R., \& Schroder, B. (2006). How Smaller Born-Global Firms Use Networks and Alliances to Overcome Constraints to Rapid Internationalization. Journal of International Marketing, 14(3), 33-63.

17. Gabrielsson, M., \& Kirpalani, V. (2004). Born globals: how to reach new business space rapidly. International Business Review, 13(5), 555-571.

18. Gabrielsson, P., Gabrielsson, M., \& Seppälä, T. (2012). Marketing Strategies for Foreign Expansion of Companies Originating in Small and Open Economies: The Consequences of Strategic Fit and Performance. Journal of International Marketing, 20(2), 25-48.

19. Grant, R. M. (1996). Prospering in Dynamically-Competitive Environments: Organizational Capability as Knowledge Integration. Organization Science, 7(4), 375-387.

20. Helfat, C. E., \& Peteraf, M. A. (2003). The dynamic resource-based view: capability lifecycles. Strategic Management Journal, 24(10), 997-1010.

21. Johanson, J., \& Vahlne, J.-E. (1977). The Internationalization Process of the Firm - A Model of Knowledge Development and Increasing Foreign Market Commitments. Journal of International Business Studies, $8(1), 23-32$.

22. Johanson, J., \& Vahlne, J.-E. (1990). The Mechanism of Internationalisation. International Marketing Review, 7(4), 11-24.

23. Johanson, J., \& Wiedersheim-Paul, F. (1975). The internationalization of the firm - Four Swedish cases. Journal of Management Studies, 12(3), 305-323.

24. Johnson, G. (1988). Rethinking incrementalism. Strategic Management Journal, 9(1), 75-91.

25. Knight, G. A., \& Cavusgil, S. T. (2004). Innovation, organizational capabilities, and the born-global firm. Journal of International Business Studies, 35(2), 124-141.

26. Kogut, B., \& Zander, U. (1992). Knowledge of the Firm, Combinative Capabilities, and the Replication of Technology. Organization Science, 3(3), 383-397.

27. Lichtenthaler, U., \& Lichtenthaler, E. (2010). Technology Transfer across Organizational Boundaries: Absorptive Capacity and Desorptive Capacity. California Management Review, 53(1), 154-170.

28. Liebeskind, J. P. (1996). Knowledge, strategy, and the theory of the firm. Strategic Management Journal, 17(1), 93-107.

29. Lindblom, C. E. (1959). The Science of "Muddling Through". Public Administration Review, 19(2), $79-88$.

30. Machlup, F. (1967). Theories of the Firm: Marginalist, Behavioral, Managerial. The American Economic Review, 57(1), 1-33.

31. Madsen, T. K., \& Servais, P. (1997). The internationalization of Born Globals: An evolutionary process?. International Business Review, 6(6), 561-583.

32. Massukado-Nakatani, M. S., \& Teixeira, R. M. (2009). Resource-based view as a perspective for public tourism management research: evidence from two Brazilian tourism destinations. Brazilian Administration 
Review, 6(1), 62-77.

33. Moen, Ø. (2002). The Born Globals: A new generation of small European exporters. International Marketing Review, 19(2), 156-175.

34. Moen, Ø., Sørheim, R., \& Erikson, T. (2008). Born Global Firms and Informal Investors: Examining Investor Characteristics. Journal of Small Business Management, 46(4), 536-549.

35. Nelson, R. R., \& Winter, S. G. (1982). An Evolutionary Theory of Economic Change. Cambridge: Harvard University Press.

36. Nonaka, I. (1994). A Dynamic Theory of Organizational Knowledge Creation. Organization Science, 5(1), $14-37$.

37. Oviatt, B. M., \& McDougall, P. P. (1994). Toward a theory of international new ventures. Journal of International Business Studies, 25(1), 45-64.

38. Oviatt, B. M., \& McDougall, P. P. (1997). Challenges for Internationalization Process Theory: The Case of International New Ventures. Management International Review, 37(Special Issue), 85-99.

39. Park, T., \& Rhee, J. (2012). Antecedents of knowledge competency and performance in born globals: The moderating effects of absorptive capacity. Management Decision, 50(8), 1361-1381.

40. Penrose, E. T. (1959). The theory of the growth of the firm. Oxford: Basil Blackwell.

41. Peteraf, M. A. (1993). The cornerstones of competitive advantage: A resource-based view. Strategic Management Journal, 14(3), 179-191.

42. Petersen, B., \& Pedersen, T. (1997). Twenty years after - support and critique of the Uppsala internationalization model. In I. Björkman \& M. Forsgren (Eds.), The Nature of the International Firm (pp. 117-134). Copenhagen: Copenhagen Business School Press.

43. Polanyi, M. (1962). Tacit Knowing: Its Bearing on Some Problems of Philosophy. Reviews of Modern Physics, 34(4), 601-616.

44. Rennie, M. W. (1993). Global competitiveness: Born Global. The McKinsey Quarterly, 4, 45-52.

45. Rialp, A., Rialp, J., \& Knight, G. A. (2005). The phenomenon of early internationalizing firms: what do we know after a decade (1993-2003) of scientific inquiry? International Business Review, 14(2), 147-166.

46. Root, F. R. (1994). Entry strategies for international markets. San Francisco: Jossey-Bass.

47. Simon, H. A. (1991). Bounded Rationality and Organizational Learning. Organization Science, 2(1), 125134.

48. Solberg, C. A. (1997). A framework for analysis of strategy development in globalizing markets. Journal of International Marketing, 5(1), 9-30.

49. Spender, J. C. (1996). Making Knowledge the Basis of a Dynamic Theory of the Firm. Strategic Management Journal, 17(Winter Special Issue), 45-62.

50. Steen, J. T., \& Liesch, P. W. (2007). A note on Penrosean growth, resource bundles and the Uppsala model of internationalisation. Management International Review, 47(2), 193-206.

51. Teece, D. J. (2007). Explicating dynamic capabilities: the nature and microfoundations of (sustainable) enterprise performance. Strategic Management Journal, 28(13), 1319-1350.

52. Teece, D. J., Pisano, G., \& Shuen, A. (1997). Dynamic capabilities and strategic management. Strategic Management Journal, 18(7), 509-533.

53. Wernerfelt, B. (1984). A resource-based view of the firm. Strategic Management Journal, 5(2), 171-180.

54. Westhead, P., Wright, M., \& Ucbasaran, D. (2001). The internationalization of new and small firms. Journal of Business Venturing, 16(4), 333-358.

55. Winter, S. G. (1987). Knowledge and competence as strategic assets. In D. J. Teece (Ed.), The competitive challenge: Strategies for industrial innovation and renewal (pp. 159-184). New York: Harper \& Row.

56. Zollo, M., \& Winter, S. G. (2002). Deliberate Learning and the Evolution of dynamic capabilities. Organization Science, 13(3), 339-351. 